\title{
First record of the invasive alien species Axis axis (Erxleben, 1777) (Artiodactyla: Cervidae) in Brazil
}

\author{
Jonas Sponchiado ${ }^{1}$, Geruza Leal Melo² \& Nilton Carlos Cáceres ${ }^{3,4}$ \\ ${ }^{1}$ Programa de Pós-graduação em Biodiversidade Animal, CCNE, \\ Universidade Federal de Santa Maria - UFSM, CEP 97110-970, Camobi, Santa Maria, RS, Brazil \\ ${ }^{2}$ Programa de Pós-graduação em Ecologia e Conservação, CCBS, \\ Universidade Federal do Mato Grosso do Sul-UFMS, CP 549, CEP 79070-900, \\ Campo Grande, MS, Brazil \\ ${ }^{3}$ Laboratório de Ecologia e Biogeografia, Departamento de Biologia, \\ Universidade Federal de Santa Maria - UFSM, CEP 97110-970, Camobi, Santa Maria, RS, Brazil \\ ${ }^{4}$ Corresponding author: Nilton Carlos Cáceres, e-mail: niltoncaceres@ gmail.com
}

SPONCHIADO, J., MELO, G.L. \& CÁCERES, N.C. First record of the invasive alien species Axis axis (Erxleben, 1777) (Artiodactyla: Cervidae) in Brazil. Biota Neotrop. 11(3): http://www.biotaneotropica.org. br/v11n3/en/abstract?short-communication+bn00611032011

\begin{abstract}
The exotic alien species Axis axis was introduced in the Americas at the beginning of last century and since then has established itself, expanding its distribution. This is the first record of this species in Brazil. In the extreme south of the country, an individual of A. axis was recorded with a camera trap in the Espinilho State Park. The area is close to the border of Uruguay and Argentina, countries where the species is established and from where this individual presumably originated. The Pampas biome is strongly disturbed by human activity in Brazil and since many native mammal species such as the Pampas deer Ozotoceros bezoarticus are threatened regionally. It is alarming that exotic populations can potentially rapidly expand their ranges in the region, as $A$. axis deer has done in Uruguay and Argentina. Possible consequences for this invasion are discussed.

Keywords: Pampas biome, introduction, exotic species, interference competition, Ozotoceros bezoarticus.
\end{abstract}

SPONCHIADO, J., MELO, G.L. \& CÁCERES, N.C. Primeiro registro da espécie exótica invasora Axis axis (Erxleben, 1777) (Artiodactyla: Cervidae) no Brasil. Biota Neotrop. 11(3): http://www.biotaneotropica.org. br/v11n3/pt/abstract?short-communication+bn00611032011

Resumo: A espécie exótica invasora Axis axis foi introduzida no continente americano no início do século passado e desde então se estabeleceu, ampliando sua distribuição. Este é o primeiro registro da espécie para o Brasil. No extremo sul do país, um indivíduo de A. axis foi registrado com armadilha fotográfica, no Parque Estadual do Espinilho. A área é muito próxima a divisa com Uruguai e Argentina, países onde a espécie esta estabelecida e de onde provavelmente o espécime é originário. Visto que o bioma Pampa encontra-se fortemente alterado no Brasil e que muitas espécies da fauna de mamíferos nativa estão ameaçadas de extinção regionalmente, como o veado-campeiro Ozotoceros bezoarticus, é preocupante que populações exóticas estejam ampliando rapidamente sua área de distribuição na região, como fez A. axis no Uruguai e Argentina. Possíveis implicações decorrentes dessa invasão são discutidas.

Palavras-chave: bioma Pampa, introdução, espécie exóticas, competição por interferência, Ozotoceros bezoarticus. 


\section{Introduction}

The axis deer Axis axis (Erxleben, 1777) is a species of medium size, with head and body length 1.00 to $1.75 \mathrm{~m}$, shoulder height 0.60 to $1.00 \mathrm{~m}$ and body mass 27 to $110 \mathrm{~kg}$ (Nowak 1991). The general coloration is reddish-brown with white spots present in the juvenile and persisting into adulthood. The abdomen, rump, neck, inner legs, ears and tail are white (Schaller 1967). Males have a pair of three-pointed antlers that are replaced annually (Nowak 1991).

Native to Asia (India, Nepal and Sri Lanka), the species is crepuscular in habits, inhabiting a variety of habitats from grasslands to open forest, but rarely penetrating dense forest. It is a social animal, typically in groups of 5 to 10 individuals; however, groups of more than 200 individuals have been reported (Nowak 1991). This species was introduced in several countries as an ornamental species, as a food resource, and for sport hunting (Lever 1985, Mares \& Ojeda
1984). In the Americas it is present in USA, Mexico, Argentina and Uruguay (Achaval et al. 2007, Instituto... \& México 2000, Novillo \& Ojeda 2008, Fass \& Weckerly 2010).

In the present study we describe the first record of the invasive alien species Axis axis in Brazil.

\section{Material and Methods}

The record presented here was obtained in Espinilho State Park $\left(30^{\circ} 11^{\prime} 21^{\prime \prime} \mathrm{S}\right.$ and $\left.57^{\circ} 29^{\prime} 53^{\prime \prime} \mathrm{W}\right)$, with an area of 1,617 ha, the park is located in Barra do Quaraí municipality, extreme western Rio Grande do Sul in southern Brazil (Figure 1). The Quaraí River forms the southern border of this municipality with Uruguay, and to the west the Uruguay River forms its border with Argentina. Part of the Pampas biome, the dominant vegetation is a type of scrubland prairie, composed mainly of homogeneously spaced thorny trees with no canopy overlap, which has allowed the formation of extensive

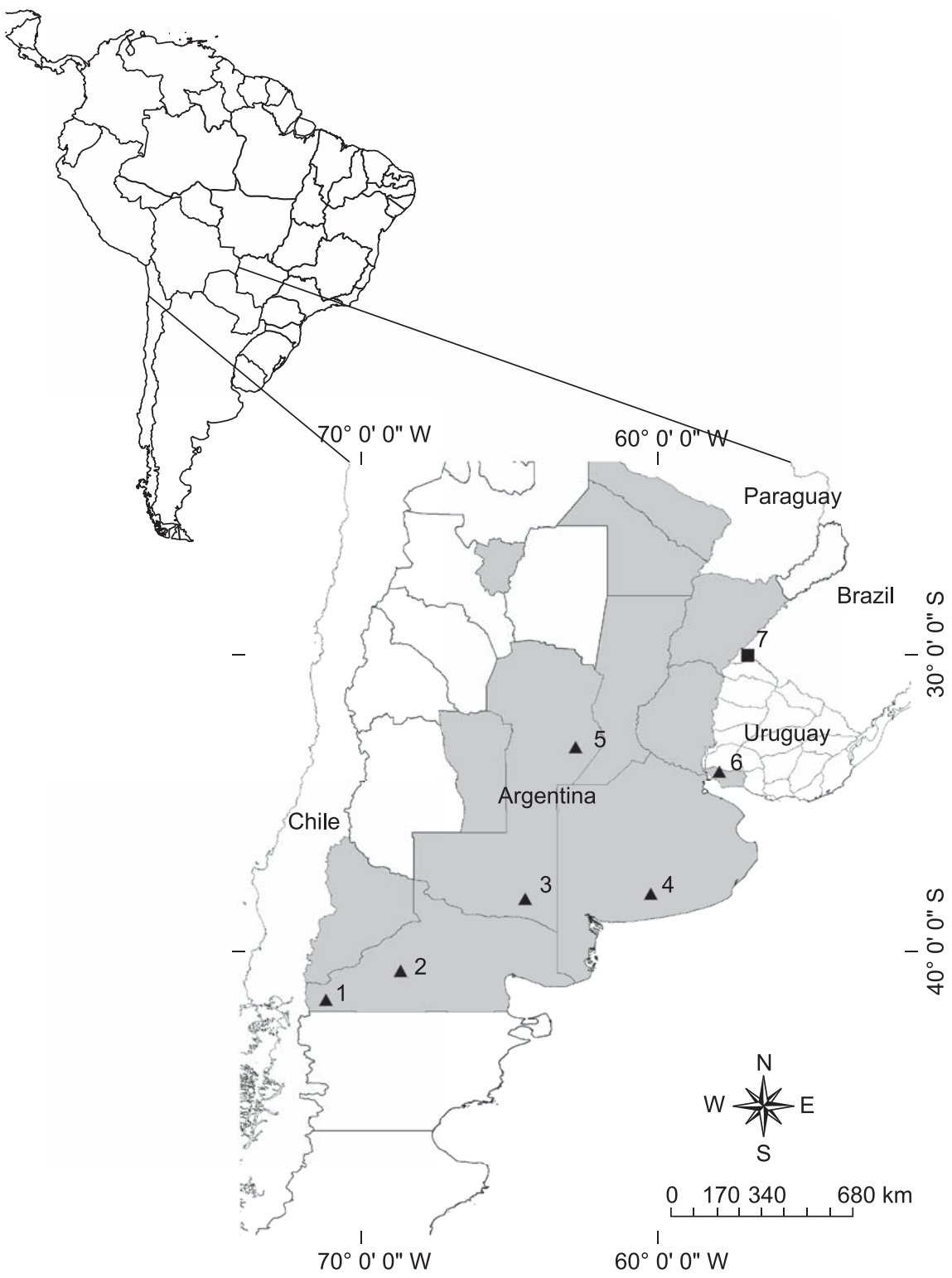

Figure 1. Localities with records of Axis axis. Triangles show the localities of introduction of A. axis in Argentina and Uruguay. Square shows the locality of Espinilho State Park, Barra do Quaraí municipality, Rio Grande do Sul State, Brazil, where A. axis was recorded in the present study. The gray area corresponds to the provinces of Argentine and department of Uruguay where the species currently occurs in wild populations. 1 - Neuquén ( $41^{\circ} 43^{\prime} \mathrm{S}$ and $71^{\circ} 17^{\prime}$ W), 2 - Río Negro, $\left(40^{\circ} 45^{\prime} \mathrm{S}\right.$ and $\left.68^{\circ} 00^{\prime} \mathrm{W}\right), 3-\mathrm{La}$ Pampa ( $38^{\circ} 14^{\prime} \mathrm{S}$ and $\left.64^{\circ} 32^{\prime} \mathrm{W}\right), 4-$ Buenos Aires (37 $59^{\prime} \mathrm{S}$ and $\left.60^{\circ} 05^{\prime} \mathrm{W}\right), 5-\mathrm{Santa} \mathrm{Fe}\left(33^{\circ} 08^{\prime} \mathrm{S}\right.$ and $\left.62^{\circ} 57^{\prime} \mathrm{W}\right)$, 6 - Colonia ( $34^{\circ} 01^{\prime} \mathrm{S}$ and $\left.57^{\circ} 56^{\prime} \mathrm{W}\right)$ and 7 - Espinilho State Park ( $30^{\circ} 11^{\prime} \mathrm{S}$ and $\left.57^{\circ} 29^{\prime} \mathrm{W}\right)$. 
grassland (Veloso et al. 1991). Three leguminous, thorny, deciduous tree species that rarely exceed $5 \mathrm{~m}$ in height dominate the landscape: Prosopis algarrobilla Griseb., Acacia farnesiana (L.) Willdenow and A. caven (Mol.) Molina (Leite 2002). Riparian vegetation in this formation consists mainly of species of Myrtaceae and Fabaceae (Galvani \& Baptista 2004). According to the Köeppen classification, the climate is $\mathrm{Cfa}$ (humid subtropical) and altitude ranges between 40 and $70 \mathrm{~m}$ above sea level. The average annual rainfall is $1300 \mathrm{~mm}$, well distributed rainfall throughout the year. Average summer temperature is $26{ }^{\circ} \mathrm{C}$, with maximum reaching $38^{\circ} \mathrm{C}$. Mean winter temperature is $15^{\circ} \mathrm{C}$, though it can occasionally dip below zero.

The individual documented here was recorded during an inventory of mammal species carried out between November 2009 to September 2010, in which 15 camera-traps (spaced at least $500 \mathrm{~m}$ from each other) were monitored for six full days during six bimonthly field phases, totalling an effort of $12,960 \mathrm{~h}$ of camera trapping.

\section{Results and Discussion}

On December 04, 2009 a male individual of A. axis was recorded at 11:45 PM by a Tigrinus ${ }^{\circledR}$ Digital 6.0D camera trap (Figure 2). The trap was attached to a tree trunk about $30 \mathrm{~cm}$ above the ground, and baited with pieces of ham and corn mixed with cod-liver oil. The record was about $5.5 \mathrm{~km}$ from the Argentinean border inside the Brazilian territory.

Certain literature citations suggest that the species may have been previously introduced into Brazil (Duckworth et al. 2008, Nowak 1991), but no specific location, release date or specimen have ever been documented. Indeed, we were unable to find any basis for these reports in the available literature. This record therefore represents the first confirmed occurrence of this species in Brazil.

In Uruguay, A. axis was first introduced in 1930 in Estancia San Juan, department of Colonia, where it established and expanded (Achaval et al. 2007). In Argentina, it was introduced in the province of La Pampa in 1906 (Lever 1985), in the province of Buenos Aires in 1930 (Navas 1987), and later in Santa Fe, Neuquén and Río Negro (Petrides 1975), where the species is established in wild populations and is expanding its distribution in the country. Its current distribution in Argentina also includes the provinces of Formosa, Chaco, Corrientes, Córdoba, Entre Rios, Tucumán e San Luis (J. C. Chebez, personal communication).

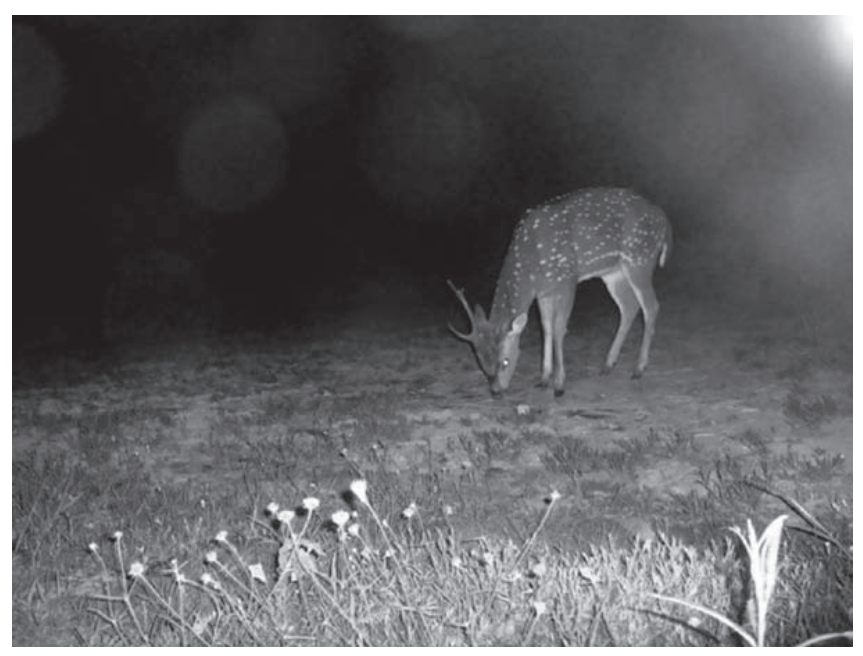

Figure 2. The invasive alien species Axis axis recorded for the first time for Brazil in the Espinilho State Park, Barra do Quaraí municipality, western Rio Grande do Sul State.
We believe that the individual found in the Espinilho State Park originates from Argentina, as the species has undergone a recent northward expansion in that country, bringing it closer to the border with Brazil (Novillo \& Ojeda 2008). The location of this record represents a natural extension of that range expansion (Figure 1). Nowak (1991) states that this species is a good swimmer, and thus the Uruguay River, which has a slow water flow and is as narrow as $600 \mathrm{~m}$ wide on the park boundaries would not represent a physical barrier to dispersal into Brazil. It is unlikely that the individuals appearance in Brazil was human assisted, as there is intense border survey and law enforcement on the Brazilian and Argentinean border by officers from both countries.

In the southern United States, Faas \& Weckerly (2010) showed that $A$. axis outcompetes the native White-tailed Deer, Odocoileus virginianus Zimmermann, 1780, by interference. In the Pampas biome, the endangered Pampas deer Ozotoceros bezoarticus (Linnaeus, 1758), may suffer from a similar competitive impact where axis deer is present, since both theoretically employ the same food resources and habitats (Achaval et al. 2007, Machado et al. 2008, Nowak, 1991). In addition, the alien species larger body size confers an advantage in interference competition, as observed with O. virginianus in the southern United States (Faas \& Weckerly 2010). In the vicinity of our study area, O. bezoarticus has suffered from widespread local extinction (Cáceres et al. 2007, Fontana et al. 2003) because of the poor state of conservation of the Pampas biome (Overbeck et al. 2007). Worryingly it is this habitat degradation that could facilitate further expansion of this exotic species in the Brazilian territory, if a nuclear population successfully crosses the Uruguay River into Brazil.

Specific studies are required to evaluate whether established populations of $A$. axis already exist in this poorly known region of Brazil.

\section{Acknowledgements}

Our thanks to Mauricio Barbanti Duarte for confirming the species identification. To our colleagues of the Laboratório de Ecologia e Biogeografia of the Universidade Federal de Santa Maria: Brisa Peres, Suelen Roani and Franchesco Della-Flora, for helping in the fieldwork. To Conselho Nacional de Desenvolvimento Científico e Tecnológico for a scholarship to the first author, and for financial support to NCC (Edital 06/2008 - Jovens Pesquisadores, Processo 569182/2008-5). NCC is a CNPq-research fellow in Brazil. We thank Paul Smith for helping in the English correctness of the text.

\section{References}

ACHAVAL, F., CLARA, M. \& OLMOS, A. 2007. Mamíferos de La República Oriental del Uruguay. Zonalibro Industria Gráfica, Montevideo.

CÁCERES, N.C., CHEREM, J. \& GRAIPEL, M.E. 2007. Distribuição geográfica de mamíferos terrestres na Região Sul do Brasil. Ciênc. Amb. 35:167-180.

DUCKWORTH, J.W., KUMAR, N.S., ANWARUL ISLAM, M.D., BARAL, H.S. \& TIMMINS, R.J. 2008. Axis axis. In IUCN Red List of Threatened Species. (International Union for Conservation of Nature - IUCN). Version 2010.3. Disponível em www.iucnredlist.org (último acesso em $12 / 09 / 2010)$.

FASS, C.J. \& WECKERLY, F.W. 2010. Habitat Interference by Axis Deer on White-Tailed Deer. J. Wild. Manage. 74(4):698-706. http://dx.doi. org/10.2193/2009-135

FONTANA, C.S., BENCKE, G.A. \& REIS, R.E. 2003. Livro vermelho da fauna ameaçada de extinção no Rio Grande do Sul. EdiPUCRS, Porto Alegre. 
GALVANI, F.R. \& BAPTISTA, L.R.M. 2004. Flora do Parque Estadual do Espinilho, Barra do Quarai, RS. Rev. Fac. Zoo. Vet. e Agro. 10:148-168.

INSTITUTO NACIONAL DE ECOLOGÍA - INE \& MEXICO. Secretaría de medio ambiente y recursos naturales - SEMARNAT. 2000. Base de datos electrónica del Sistema de Unidades de Manejo, Conservación y Aprovechamiento de la Vida Silvestre SUMA. SEMARNAT, México. Reporte interno de la Dirección General de Vida Silvestre.

LEITE, P.F. 2002. Contribuição ao conhecimento fitoecológico do sul do Brasil. Ciênc. Amb. 1:51-53.

LEVER, C. 1985. The naturalized mammals of the World. Longman Science \& Technology, England.

MACHADO, A.B., DRUMMOND, G.M. \& PAGLIA, A.P. 2008. Livro Vermelho da Fauna Brasileira Ameaçada de Extinção. Ministério do Meio Ambiente, Brasília.

MARES, M.A. \& OJEDA, R.A. 1984. Faunal commercialization and conservation in South America. BioScience 34:580-584.

NAVAS, J. 1987. Los vertebrados exóticos introducidos en La Argentina. Rev. Del. MACN “Bernardino Rivadavia”' 14.
NOVILLO, A. \& OJEDA, R.A. 2008. The exotic mammals of Argentina. Biol. Invas. 10(8):1333-1344.

NOWAK, R.M. 1991. Walker's mammals of the world. John Hopkins Univ. Press, Baltimore.

OVERBECK, G.E., MÜLLER, S.C., FIDELIS, A., PFADENHAUER, J., PILLAR, V.D., BLANCO, C.C., BOLDRINI, I.I., BOTH, R., FORNECK, E.D., 2007. Brazil's neglected biome: The South Brazilian Campos. Persp. Plant. Eco. Evol. Syst. 9:101-116. http://dx.doi.org/10.1016/j. ppees.2007.07.005

PETRIDES, G.A. 1975. The importation of wild ungulates into Latin America, with remarks on their environmental effects. Environ. Conserv. 2:47-51. http://dx.doi.org/10.1017/S0376892900000667

SCHALLER, G.B. 1967. The Deer and the Tiger. A study of Wildlife in India. The University of Chicago Press, Chicago.

VELOSO, H.P., RANGEL-FILHO, A.L.R. \& LIMA, J.C.A. 1991. Classificação da vegetação brasileira adaptada a um sistema universal. IBGE, Rio de Janeiro. 